\title{
PERSEPSI SISWA KELAS X TENTANG KREATIVITAS MENGAJAR GURU PAK DALAM MENGGUNAKAN ILMU PENGETAHUAN DAN TEKNOLOGI DI SMA NEGERI 1 SIBORONG-BORONG KABUPATEN TAPUT TAHUN PEMBELAJARAN 2018/2019
}

\author{
Ronny Simatupang \\ Institut Agama Kristen Negeri Tarutung \\ Email: ronnysimatupang75@gmail.com
}

\begin{abstract}
Abstrak: Penelitian ini bertujuan untuk mengetahui Persepsi Siswa Kelas X Tentang Kreativitas mengajar guru PAK Dalam Menggunakan IPTEK di SMA Negeri 1 Siborong-borong Kabupaten Taput Tahun Pembelajaran 2018/2019, dengan hipotesa> $70 \%$ dari yang diharapkan. Penelitian ini menggunakan metode kuantitatif deskriptif, dengan populasi penelitian seluruh siswa kelas X yang berjumlah 163 orang dan sampel diambil $30 \%$ sehingga sampel berjumlah 49 orang. Instrument penelitian berupa angket tertutup. Uji coba dilakukan dengan menggunakan teknik sample random kepada 30 siswa kelas $\mathrm{X}$ di luar sampel penelitian. Uji validitas instrumen dengan menggunakan rumus Koefisien Korelasi Product Moment Pearson diperoleh $\mathrm{r}$ hitung > r tabel $(0,05.30)$ yaitu berada diantara 0,424 s/d 0,728>0,361 dengan demikian instrumen dikategorikan valid. Dan uji reliabilitas instrument dengan rumus Formula Alpha diperoleh r $11=0.930$ berada pada kategori sangat tinggi, dengan demikian instrument reliabel. Dari hasil analisis data diperoleh nilai Persepsi Siswa Kelas X Tentang Kreativitas mengajar guru PAK Dalam Menggunakan IPTEK di SMA Negeri 1 Siborong-borong $=77.01 \%$ berada pada kategori baik, artinya siswa sudah memahami dengan baik Kreativitas mengajar guru PAK Dalam Menggunakan IPTEK. Hasil analisis indikator berada pada kategori baik, setiap item angket menunjukkan bahwa hasil persepsinya pada umumnya sudah berada pada kategori baik dan sangat baik. Berdasarkan uji $\mathrm{t}$ diperoleh $\mathrm{t}$ hitung dengan $\mathrm{t}$ tabel $=5,651>\mathrm{t}$ tabel $=1,684$, maka disimpulkan bahwa Persepsi Siswa Kelas X Tentang Kreativitas mengajar guru PAK Dalam Menggunakan IPTEK di SMA Negeri 1 Siborong-borong $>70 \%$ diterima kebenarannya.

Kata Kunci: Kreativitas mengajar guru PAK Dalam Menggunakan IPTEK
\end{abstract}

\section{PENDAHULUAN}

Pendidikan adalah suatu usaha untuk membentuk kepribadian dengan jalan membina, mendidik dan melatih pribadi seseorang sehingga mengalami perubahan tingkah laku kearah yang lebih dewasa di dalam segala tindakannya sehari-hari dan sekaligus untuk mencapai kehidupan yang lebih sukses dikemudian hari. Tujuan pendidikan pada umumnya ialah suatu pembelajaran yang terdiri dari pelajar dan pengajar sehingga pendidikan tersebut bisa didapatkan kejenjang paling tinggi baik secara sosial, maupun secara falsafah kehidupan. Sekolah merupakan 
lembaga prendidikan yang di dalamnya terjadi proses belajar-mengajar, di mana guru sebagai pendidik dan siswa sebagai peserta didik yang menerima pelajaran. Untuk itu peranan guru sangat menentukan proses belajar untuk mencapai tujuan penfdidikan nasional, maka sangat dibutuhkan guru-guru yang memiliki kemampuan dan kecakapan yang memadai, memiliki cara-cara yang kreatif dan memiliki sikap yang dapat diteladani.

Untuk mencapai tujuan pendidikan peran guru sangat penting. Guru adalah orang yang bertanggung jawab mencerdaskan kehidupan anak didik. Dalam proses belajar guru mempunyai tugas mendorong, membimbing dan memberi fasilitas belajar bagi siswa untuk mencapai tujuan pembelajaran. Guru juga mempunyai tanggung jawab untuk melihat segala sesuatu yang terjadi dalam kelas untuk membantu proses perkembangan siswa. Khususnya di sekolah sangat dibutuhkan guru yang mempunyai kreativitas dalam mengajar, karena kreativitas seorang guru dalam mengajar sangat didambakan oleh setiap orang khususnya anak didik.

Kegiatan belajar mengajar merupakan suatu kegiatan yang disengaja diciptakan guru yang mengajar dan peserta didik yang belajar. dalam kegiatan belajar penting dilakukan guru adalah mencipotakan kondisi atau suatu proses yang mengarahkan peserta didik untuk melakukan aktivitas belajar. dalam hal ini peran guru sangat penting, bagaimana guru melakukan usaha-usaha untuk dapat menumbuhkan motivasi agar peserta didik melakukan aktivitas belajar dengan baik.

Orang yang mengasihi Tuhan diberi potensi menjadi orang yang kreatif. Guru yang mempunyai kreativitas adalah seorang pekerja keras. Sebab firman Tuhan berkata "Tetapi baiklah ia bekerja keras dan melakukan pekerjaan yang baik dengan tangannya sendiri, supaya ia dapat membagikan sesuatu kepada orang yang berkekurangan", (Efesus 4:28). Kreativitas didorong adanya imajinasi dan juga hasil pemikiran untuk menciptakan hal-hal yang diingankan, seseorang yang dapat melihat dan berpikir mampu memiliki gagasan- gagasan atau ide-ide yang baru. Juga kreativitas guru dapat menggairahkan atau memotivasi belajar anak didik untuk menyerap bahan pelajaran. Karena kreativitas yang dimiliki guru akan mengaktifkan anak didik dalam proses pembelajaran sehingga mereka tidak ingin pelajaran itu berakhir artinya mereka termotivasi untuk belajar. demikian juga dalam pembelajaran Pendidikan Agama Kristen, keberhasilan kegiatan belajar mengajar juga ditentukan oleh kreativitas Guru PAK dalam mengajar.

Ilmu pendidikan dan teknologi (IPTEK) hadir sebagai akibat dari aktivitas dalam memenuhi kebutuhan manusia, baik kebutuhan jasmani maupun kebutuhan rohani. Kemajuan IPTEK tidak bisa dipisahkan dari lembaga pendidikan. IPTEK adalah unsur universal budaya (Cultural Universal), artinya IPTEK dapat ditemui dalam semua aspek kebudayaan dan dikembangkan untuk mempertahankan dan meningkatkan mutu hidup serta kehidupan manusia. Sesuai dengan kondisi era globalisasi di mana terdapat pembangunan dan kemajuan IPTEK yang merubah segala sistem bahkan pola pikir manusia saat ini. Ketika IPTEK pertama kali diciptakan, orang menganggap bahwa kehidupan akan lebih baik. Informasi lebih cepat tersampaikan kepada orang banyak dan produk baru akan tersampaikan atau diketahui publik. Banyak Guru PAK yang kurang memahami dan kurang kreatif dalam menggunakan berbagai macam-macam IPTEK dengan baik dan tepat saat ini. Karena kurang disosialisasikan oleh lembaga pendidikan pemerintah, guru PAK saat ini harus memiliki kreativitas dalam mengajar dengan menggunakan IPTEK sehingga anak didik akan lebih cepat menangkap dan termotivasi dalam pembelajaran yang diberikan oleh guru PAK.

IPTEK sebagai sumber belajar kurang dimanfaatkan bagi para guru terkhususnya guru PAK, guru PAK kurang kreatif dan kurang mengerti dalam menggunakan 
Teknologi sebagai sumber belajar sehingga kurang dilaksanakan dan kurang optimal. Dari data yang dilihat dan penulis ketahui penggunaan IPTEK sebagai sumber belajar tidak terealisasikan dengan baik seperti TV, komputer, infocus, media massa sebagai sumber belajar. Guru malas menciptakan hal-hal yang baru dengan penggunaan berbagai IPTEK yang ada di sekolah. Akibatnya anak didik malas belajar dan tidak semangat untuk mengikuti proses belajar mengajar, kurangnya tingkat kemajuan yang dimiliki anak didik baik dari segi intelektual dan tingkat kerohanian.

Menurut Rusman (2012:324) bahwa: pembelajaran kreatif adalah proses pembelajaran yang mengharuskan guru dapat memotivasi dan memunculkan kreativitas siswa selama pembelajaran berlangsung, dengan menggunakan beberapa metode dan strategi yang bervariasi, kerja kelompok, bermain peran, dan pemecahan masalah. Yang menjadi dasar teologis "Mengajar haruslah dengan kreatif", adalah sebagai berikut: 1). Allah sendiri adalah Kreatif. Kitab Mazmur 19:2 "Langit menceritakan kemuliaan Allah, dan cakrawala memberikan pekerjaan tangan-Nya". Allah menciptakan langit dan cakrawala dengan indahnya. Hal ini sungguh mengungkapkan betapa hebatnya Allah menciptakan langit dan cakrawala. Tidak ada seorangpun yang sanggup menciptakan langit dan cakrawala.

Allah adalah sumber kreativitas yang utama karena Dialah yang pencipta Alam Semesta beserta isinya (Kej.1-2). 2). Yesus Kristus. Dalam pelayanan Yesus untuk memberikan Kerajaan Allah sudah dekat, Yesus banyak menggunakan metode mengajar yang kreatif, yang sesuai dengan kebutuhan mereka pada saat ini. Beberapa metode yang digunakan Yesus dalam pengajaran-Nya, yaitu: a) Dengan menggunakan kata-kata, contoh dalam Mat. 16:18 "dan Aku pun berkata kepadamu: Engkau adalah Petrus dan di atas batu karang ini Aku akan mendirikan jemaat-Ku dan alam maut tidak akan menguasainya".

Dalam bahasa Yunani, kata Petrus memiliki sinonim (arti kata yang sama) dengan kata batu karang. Contoh yang lain dalam Mat.23:24 "Hai kamu pemimpinpemimpin buta, nyamuk kamu tapiskan dari dalam minumanmu, tetapi unta dibandingkan Yesus, sebagai suatu teguran bagi para ahli Taurat dan orang-orang Farisi. b) Yesus menggunakan kiasan atau metafora, yaitu kata garam dunia dan terang dunia (Mat. 5:13-16), Ular beludak (Mat.3:7,12:34;23:33). c) Perumpamaan, banyak sekali dalam pengajaran Yesus memberikan cerita dalam bentuk perumpamaan, contoh perumpamaan tentang biji sesawi, seorang penabur dan sebagainya. d) Bahasa gambar, Mat. 6:26 kepada murid- murid-Nya yang sedang kuatir akan masa depan mereka, Yesus berkata: "Pandanglah burung-burung di langit, yang tidak menabur dan tidak menuai dan tidak mengumpulkan bekal dalam lumbung, namun diberi makan oleh Bapamu yang di sorga. Bukankah kamu jauh melebihi burung-burung itu?". Menurut Saleh (2013:58-64) bahwa beberapa cara mengajar kreatif yang dilakukan guru dalam pembelajaran yaitu: 1).

Membuat Lembar Kerja yang menarik. Buku merupakan alat sekaligus sumber pembelajaran yang paling utama dalam kegiatan mengajar. Selain itu, buku pun memiliki peranan yang cukup besar dalam proses pembelajaran bagi para anak didik dikelas. Ia tidak akan bergantung pada buku yang digunakan oleh anak-anak didik dalam proses pembelajaran. Bahkan, guru yang kreatif dapat "menyulap" materi pelajaran yang akan disampaikan menjadi sesuatu yang baru. Salah satunya adalah membuat lembar dengan tampilan yang disukai anak-anaknya. 2). Menggunakan Alat Permainan. Dibanding dengan kegiatan belajar, sebagian besar anak didik lebih tertarik dengan kegiatan bermain. Dalam pemikiran mereka, bermain lebih menyenangkan daripada belajar. guru yang memiliki kemampuan mengajar kreatif 
mampu menggabungkan dua kegiatan, bermain sambil berlajar. 3). Membuat soal ulangan yang baik. Ulangan sangat identik dengan sesuatu yang formal dan kaku. Soal disajikan dalam lembaran kertas yang bertuliskan nama anak didik, kelas, tanggal ulangan, waktu pengerjaan, aturan-aturan pengerjaan, sampai logo sekolah. Ternyata format seperti ini mampu mempengaruhi konsentrasi pada anak- anak didik ketika mengerjakan soal-soal ulangan. Soalsoal yang dibuat harus mencakup indikator pembelajaran yang telah di tentukan.

Briggs dalam Sadirman (2010:6) mengatakan bahwa media pembelajaran adalah segala alat fisik yang dapat menyajikan pesan serta merangsang siswa untuk belajar, buku, film, kaset, film bingkai adalah contoh-contohnya. a). Televisi. Televisi merupakan sarana yang ampuh untuk menyiarkan acara pendidikan kepada khalayak yang jumlahnya sangat banyak yang mana meningkatkan pengetahuan dan penalaran masyarakat. Pemerintah Indonesia melalui kemendiknas dan pustekom telah menyiarkan TV-Edukasi (TVe) yang selalu sering menyiarkan program-program pendidikan dan pembelajaran seperti program siaran penayangan mata pelajaran untuk menghadapi UN. Televisi dapat digunakan dalam pembelajaran sebagai pengganti guru dalam berceramah, di mana dibantu dengan DVD dan bahan ajar yang telah dirancang pemerintah dalam bentuk VCD sehingga anak didik lebih mudah menerima pembelajaran dengan baik karena dibarengi dengan baik karena dibarengi dengan gambar dan suara. Demikian juga halnya dalam pembelajaran PAK, TV juga sering dipakai untuk menyampaikan pembahasan materi, di mana VCD telah disediakan oleh pemerintah sesuai dengan materi pelajaran. Dengan menggunakan televisi dalam proses pembelajaran, anak didik dengan mudah mendapatkan pengetahuan dan juga mudah mengingatnya sehingga ingatan itu bermanfaat bagi siswa dan hasilnya akan memberikan penilaian yang baik di saat tes atau ujian. b). Internet. Penggunaan internet sebagai media belajar, mampu mengkondisikan siswa untuk belajar secara mandiri. Para siswa juga dapat mengakses secara on-line dari berbagai perpustakaan, museum, database, dan mendapatkan sumber primer tentang berbagai informasi peristiwa. Siswa dan guru fisik di kelas, karena siswa dapat mempelajari bahan ajar dengan mengakses jaringan komputer yang telah ditentukan secara online. Internet juga sering digunakan dalam pembelajaran PAK, di mana dalam mencari informasi atau tugas yang diberikan oleh guru sering kali siswa mencari jawabannya melalui internet atau sebaliknya guru menyuruh siswa untuk menemukan jawaban atas pertanyaan dari internet. Internet juga digunakan dalam membantu pekerjaan atau tugas menjadi lebih mudah, di mana guru PAK menugaskan siswanya mengumpulkan tugas melalui email.c).

Komputer. Saat ini teknologi komputer tidak lagi hanya digunakan sebagai sarana pengolahan data dan kata, tetapi juga sebagai sarana belajar multimedia. Sajian multimedia dapat mengoptimalkan proses pembelajaran lebih bermakna karena mampu menampilkan teks, warna, suara, video, gerak, gambar serta mampu menampilkan kepintaran yang dapat menyajikan proses interaktif. Komputer memberikan fasilitas yang cukup banyak untuk digunakan dalam proses pembelajaran. Pembelajaran tidak akan membosankan jika guru memberikan media melalui multi media powerpoint. Dengan menggunakan powerpoint dibantu dengan sinar in-focus, materi yang akan disampaikan dapat dilihat menarik untuk dibaca oleh naradidik. d). Majalah atau surat kabar media (media cetak). Selain itu, naradidik juga mampu memberikan pendapat sendiri dan menerangkan hasil pekerjaan yang telah diselesaikan oleh naradidik saat proses pembelajaran yang 
membuat guru dan siswa terbantu secara praktis untuk memperoleh tambahan informasi dari materi pelajaran PAK. Menurut Wina Sanjaya (2006:173) ada beberapa prinsip yang perlu dipertimbangkan dalam pemilihan dan penggunaan media antara lain sebagai berikut: 1). Media yang digunakan oleh guru harus sesuai dan diarahkan untuk mencapai tujuan pembelajaran. Media tidak digunakan sebagai alat hiburan, atau tidak semata- mata. Dimanfaatkan

untuk mempermudah guru menyampaikan materi, akan tetapi benar-benar untuk membantu siswa belajar sesuai dengan tujuan yang ingin dicapai. 2). Media yang digunakan harus sesuai dengan materi pembelajaran. Setiap materi pembelajaran. Setiap materi pelajaran memiliki kekhasan dan kekompleksan. Media yang akan digunakan harus sesuai dengan komleksitas materi pelajaran. 3). Media pembelajaran harus sesuai dengan minat, kebutuhan, dan kondisi siswa. Setiap siswa memiliki kemampuan dan gaya yang berbeda. Guru perlu memerhatikan setiap kemampuan dan gaya yang berbeda. Guru perlu memperhatikan setiap kemampuan dan gaya tersebut. 4). Media yang digunakan harus memperhatikan efektivitas dan efisien. Media yang memerlukan peralatan yang mahal belum tentu efektif untuk mencapai tujuan tertentu. Demikian juga media yang sangat sederhana belum tentu tidak memiliki nilai. Setiap media yang dirancang guru perlu memperhatikan efektivitas sesungguhnya. 5). Media yang digunakan harus sesuai dengan kemampuan guru dalam mengoperasikannya. Media secanggih apapun tidak akan bisa menolong tanpa kemampuan teknis mengoperasikan dan memanfaatkan media yang digunakan.

Alkitab telah memberi mandat kepada manusia untuk berakal dan berilmu (Kej. 1:27-28). Ilmu pengetahuan bukanlah musuh bagi orang beriman, melainkan merupakan jalan untuk lebih mengenal dan beribadat kepada sang pencipta. Rasa kagum terhadap semesta dapat menimbulkan penghargaan besar terhadap penciptanya dan orang Kristen perlu memahami hubungan antara Alkitab dengan IPTEK. Sebagai umat Kristen, kita mendasarkan iman dan percaya atas firman Tuhan yang tertulis dalam Alkitab.

Pada saat yang sama kita hidup dalam satu masa dimana IPTEK sedang berkembang pesat, sehingga seluruh segi kehidupan manusia didunia diwarnai oleh hasil penemuan ilmu pengetahuan dan teknologi modern. Brotosudarmo (2008:122:123) juga mengemukakan dalam bidang pendidikan bahwa IPTEK sangat dirasakan manfaatnya untuk meningkatkan sarana belajar mengajar, contoh pemanfaatannya adalah: a). peralatan yang dibutuhkan siswa, misalnya: kalkulator, pena, pulpen, pensil, tas, dan buku. b). Sarana pengajaran. Misalnya: white board, spidol, papan tulis, kapur, OHP, LCD, komputer, Internet, Microsoft dan alat- alat dilaboratorium biologi, fisika dan kimia. c). Gedung-gedung peserta ruangannya, laboratorium, koperasi, perpustakaan, kafe sekolah, lapangan olahraga, ruang media dan lain-lain.

Menurut Sudjana yang dikutip Djamarah dan Zain (2006:152) mengemukakan: "Fungsi media menjadi enam kategori, yaitu: 1). Penggunaan media dalam proses belajar mengajar bukan merupakan fungsi tambahan, tetapi mempunyai fungsi sendiri. Sebagai alat bantu untuk mewujudkan situasi belajar mengajar yang efektif. 2). Penggunaan media pembelajaran merupakan bagian yang integral dari keseluruhan situasi mengajar. 3). Media pembelajaran dalam pengajaran, penggunaannya integral dengan tujuan dari isi pengajaran. 4). Penggunaan media dalam pengajaran bukan sematamata alat hiburan, dalam arti digunakan hanya sekedar melengkapi proses belajar supaya lebih menarik perhatian siswa. 5). Penggunaan media dalam pengajaran lebih 
diutamakan untuk mempercepat proses belajar mengajar dan membantu siswa dalam menangkap pengertian yang diberikan guru. 6). Penggunaan media dalam pengajaran diutamakan untuk mempertinggi mutu belajar mengajar.

Selanjutnya Rusman (2012:75) mengemukakan bahwa tujuan IPTEK dalam pembelajaran adalah: 1). Menyadarkan siswa akan potensi perkembangan IPTEK yang terus berubah sehingga siswa dapat termotivasi untuk mengevaluasi dan mempelajari IPTEK sebagai dasar untuk belajar sepanjang hayat. 2). Memotivasi kemampuan siswa untuk bisaberadaptasi dan mengantisipasi perkembangan IPTEK, sehingga siswa bisa melaksanakan dan menjalani aktivitas kehidupan sehari-hari secara mandiri dan lebih percaya diri. 3). Mengembangkan kompetensi siswa dalam menggunakan IPTEK untuk mendukung kegiatan belajar, bekerja dan berbagai aktivitas dalam kehidupan sehari-hari. 4). Mengembangkan kemampuan belajar berbasis IPTEK, sehingga proses pembelajaran dapat lebih optimal, menarik, dan mendorong siswa terampil dalam komunikasi serta terampil mengorganisasi informasi dan terbiasa kerja sama. 5). Mengembangkan kemampuan belajar mandiri, berinisiatif, inovatif, kreatif, dan bertanggung jawab dalam penggunaan IPTEK untuk pembelajaran, bekerja dan pemecahan masalah sehari-hari.

\section{METODE}

Populasi dalam penelitian ini adalah keseluruhan siswa kelas X SMA Negeri 1 Siborong-borong berjumlah 163 orang. Yang menjadi sampel yaitu $163 \mathrm{x}$ $30 \%=49$ orang. Jenis instrumen penelitian yang digunakan adalah angket. Uji coba angket dilakukan terhadap 20 orang responden di luar sampel penelitian. Untuk mengetahui harga koefisien, penulis menggunakan rumus koefisien korelasi, dengan menggunakan rumus Product Moment dan Pearson yang ditulis Arikunto (2010:146) yaitu:

$$
r x y=\frac{N \cdot \sum X Y-\left(\sum X\right)\left(\sum Y\right)}{\sqrt{\left.\left\{N \cdot \sum X^{2}-\left(\sum X\right)^{2}\right)\right\} \sqrt{\left\{N \cdot \sum y^{2}\right.}-}}
$$

Uji keterandalan (realibilitas) instrument adalah untuk mengetahui sejauh mana hasil pengukuran dapat dipercaya, dilakukan dengan rumus formula Alpha dari Arikunto (2010:171), yaitu:

$$
\left.r_{11=\left[\frac{k}{k-1}\right]}\right]\left[\frac{\sum \sigma b^{2}}{\sigma t^{2}}\right]
$$

Menghitung nilai $t$ dengan rumus t-test sampel sebagaimana dikemukakan oleh Sugiyono (2008:96) dengan rumus:

$$
t=\frac{\bar{X}-\mu_{0}}{\frac{s}{\sqrt{n}}}
$$

Menghitung rata-rata data, dengan rumus yang dikemukakan Sugiyono (2008:49)

$$
\bar{X}=\frac{\sum X}{N}
$$

\section{HASIL}

1. Persepsi Siswa tentang Kreativitas mengajr guru PAK Dalam Menggunakan Ilmu Pengetahuan dan Teknologi Secara Keseluruhan setelah dihitung dapat ditemukan bahwa jumlah dapat ditemukan bahwa jumlah skor variabel yang diperoleh melalui pengumpulan data sebesar $=5283$

Dengan demikian nilai Persepsi Siswa Tentang Kreativitas mengajar guru PAK Dalam Menggunakan Ilmu Pengetahuan dan Teknologi $=5283$ : $6860=0.7701 .100 \%=77.01 \%$ Jadi nilai Persepsi Siswa Kelas X Tentang Kreativitas mengajar guru PAK Dalam Menggunakan Ilmu Pengetahuan dan Teknologi di SMA Negeri 1 Siborongborong Kabupaten Taput Tahun Pembelajaran 2018/2019 $=77.01 \%$ dari yang diharapkan.

2. Persepsi Siswa Tentang Kreativitas mengajar guru PAK Dalam Menggunakan Ilmu Pengetahuan dan Teknologi berdasarkan Indikator. Diperoleh nilai tertinggi pada indikator komputer dengan nilai 
$83.78 \%$, artinya persepsi siswa tentang Kreativitas mengajar guru PAK Dalam Menggunakan Ilmu Pengetahuan dan Teknologi yaitu dengan memanfaatkan komputer adalah sudah baik, sedangkan indikator paling rendah yaitu pada indikator Internet, artinya persepsi siswa tentang Kreativitas mengajar guru PAK Dalam Menggunakan Ilmu Pengetahuan dan Teknologi yaitu dengan memanfaatkan internet adalah cukup.

3. Persepsi Siswa Tentang Kreativitas mengajar guru PAK Dalam Menggunakan Ilmu Pengetahuan dan Teknologi berdasarkan item angket. Diperoleh nilai tertinggi pada item angket nomor 5 dengan nilai $91.84 \%$ yaitu tentang saat pembelajaran telah selesai dengan menayangkan video, guru PAK mempersilahkan siswa untuk bertanya juga berpendapat tentang materi pelajaran, dan nilai terendah pada item angket nomor 16 dengan nilai $46.94 \%$ yaitu tentang Ketika proses pembelajaran, guru PAK menanyakan kepada siswa sejauh mana memahami tugas yang diberikan Berdasarkan hasil penelitian diketahui bahwa perbandingan $\mathrm{t}_{\text {hitung }}=5.561>t_{\text {tabel }}=$ 1,684, maka Hipotesa alternative (Ha) diterima yaitu Persepsi Siswa Kelas $\mathrm{X}$ Tentang Kreativitas mengajar guru PAK Dalam Menggunakan Ilmu Pengetahuan dan Teknologi di SMA Negeri 1 Siborong-borong Kabupaten Taput Tahun Pembelajaran 2018/2019> $70 \%$ dari yang diharapkan, artinya berdasarkan perhitungan yang telah dilaksanakan kepada responden penelitian diperoleh nilai Persepsi Siswa Kelas Tentang Kreativitas mengajar guru PAK sudah mencapai $77.01 \%$ dari yang diharapkan.

\section{KESIMPULAN}

Berdasarkan hasil penelitian yang di temukan dalam penelitian ini maka di simpulkan bahwa Persepsi Siswa Kelas X Tentang Kreativitas mengajar guru PAK Dalam Menggunakan Ilmu Pengetahuan dan Teknologi di SMA Negeri 1 Siborong-borong Kabupaten Taput Tahun Pembelajaran 2018/2019 > $70 \%$ atau Hipotesa alternatif (Ha) diterima yaitu diketahui bahwa perbandingan $t_{\text {hitung }}$ dengan $t_{\text {tabel }}$ adalah $\mathrm{t}_{\text {hitung }}=5.561>\mathrm{t}_{\text {hitung }}=1.684$. Berdasarkan perhitungan yang telah dilaksanakan kepada responden penelitian diperoleh nilai Persepsi Siswa Kelas X Tentang Kreativitas mengajar guru PAK Dalam Menggunakan Ilmu Pengetahuan dan Teknologi di SMA Negeri 1 Siborong-borong Kabupaten Taput Tahun Pembelajaran 2018/2019 sudah mencapai $77.01 \%$ dari yang diharapkan. 


\section{DAFTAR PUSTAKA}

Abbas, Saleh.2013. Desain Bealajar Mengajar Kreatif. Yogyakarta: DIVA Pres.

Arikunto, Suharsimi. 2010. Spikologi Pendidikan, Jakarta: Rineka Cipta.

Brotosudarmo, drie. 2008. Teladan Kehidupan 2, PAK KTSP Dengan Kecerdasan Majemuk Kelas $X$, Yogyakarta, ANDI.

Djamarah, Syaiful bahri. 2006. Guru dan Anak Dalam Interaksi Edukatif, Jakarta: Rineka Cipta.

Rusman, Kurniawan. 2012. Pembelajaran Berbasis Teknologi Informasi dan Komunikasi, Jakarta: Rajawali Perst.

Sanjaya, Wina. 2006. Kurikulum dan Pembelajaran, Jakarta: Kencana.

Sugiono, 2008. Metode penelitian Kuantitatif dan Kualitatif dan $R$ dan $D$, Bandung: Alfabeta. 